\title{
Apoptosis in cumulus cells during in vitro maturation of bovine cumulus-enclosed oocytes
}

\author{
S. Ikeda, H. Imai and M. Yamada* \\ Laboratory of Reproductive Biology, Division of Applied Biosciences, Graduate School of Agriculture, \\ Kyoto University, Kyoto 606-8502, Japan
}

The aim of this study was to investigate whether apoptosis occurs in cumulus cells during in vitro maturation (IVM) of bovine cumulus-enclosed oocytes (CEOs). The bovine CEOs obtained from ovaries from an abattoir were cultured for $24 \mathrm{~h}$ in IVM medium in the presence or absence of $10 \%$ $(\mathrm{v} / \mathrm{v})$ fetal bovine serum. The developmental competence of enclosed oocytes, as assessed by the development of the blastocyst after IVF, was significantly higher in the serumtreated group than in the control group. The morphological features of apoptosis that were analysed by orcein staining were hardly detectable in the cumulus cells at the start $(0 \mathrm{~h})$ of IVM, but were evident at the end ( $24 \mathrm{~h}$ ) of IVM both in the control and serum-treated groups. Genomic DNA was extracted from CEOs at 0, 6, 12, 18 and $24 \mathrm{~h}$ of IVM and subjected to ligation-mediated PCR (LM-PCR) to detect apoptotic internucleosomal DNA fragmentation.
DNA fragmentation was hardly detectable at the start of IVM, but increased in a time-dependent manner as the IVM culture proceeded. DNA fragmentation was not observed in the oocytes, indicating that fragmentation occurs in cumulus cells. The degree of fragmentation was lower in the serum-treated group compared with the control group. The LM-PCR analysis of DNA extracted from CEOs at $24 \mathrm{~h}$ of IVM, in which the DNA had been pretreated with Klenow enzyme or T4 DNA polymerase, revealed that the characteristic forms of the DNA ends generated during cumulus cell apoptosis were mainly $3^{\prime}$-overhangs and blunt ends. In conclusion, the results of the present study demonstrate that cumulus cells in bovine CEOs spontaneously undergo apoptosis during IVM. The degree of apoptosis may be correlated with the developmental competence of the enclosed oocytes.

\section{Introduction}

In the cyclic recruitment of bovine ovarian follicles during each oestrous cycle, although a cohort of antral follicles start their growth in a wave-like pattern, only one follicle is selected for dominance and the remainder of the cohort regresses (Ginther et al., 2001). This regression of follicles is known as atresia. Atresia associated with cyclic follicle selection in farm animals seems to be initiated and manifested by the apoptosis of granulosa cells rather than of other follicular components, such as theca cells, cumulus cells and oocytes (Manabe et al., 1996; Yang and Rajamahendran, 2000).

In vitro maturation (IVM) of bovine oocytes is a well-established procedure for in vitro production of bovine embryos (Nagai, 2001). In the IVM system, a group of oocytes, which are usually enclosed within cumulus cell masses, that is, cumulus-enclosed oocytes (CEOs), is collected from a cohort of antral follicles, and then cultured until oocytes reach the second meiotic metaphase from the first meiotic prophase (germinal vesicle stage). The importance of the presence of cumulus cells during the IVM period has been demonstrated in

*Correspondence

Email: masayasu@kais.kyoto-u.ac.jp terms of developmental competence of the surrounded oocytes after IVF (Zhang et al., 1995; Kim et al., 1997; Ikeda et al., 2000). Although there have been many reports on apoptosis in bovine ovarian follicles or cultured granulosa cells (Jolly et al., 1994; Quirk et al., 2000; Yang and Rajamahendran, 2000), information on apoptosis in cumulus cells during IVM of bovine CEOs is limited (Luciano et al., 2000).

The objective of the present study was to investigate whether bovine cumulus cells in CEOs collected from ovaries derived from an abattoir undergo apoptosis during the period of IVM under conventional culture conditions. For this purpose, the morphological changes and apoptotic DNA fragmentation in cumulus cells during IVM were assessed. In addition, the characteristic forms of the DNA ends generated in apoptotic DNA fragmentation in cumulus cells were determined.

\section{Materials and Methods}

\section{Culture media}

The washing medium for collection and sampling of CEOs was modified PBS (mPBS) which contained $0.9 \mathrm{mmol} \mathrm{CaCl} \mathrm{I}^{-1}, 0.49 \mathrm{mmol} \mathrm{MgCl}_{2} \mathrm{I}^{-1}, 1.19 \mathrm{mmol}$ 
$\mathrm{NaHCO}_{3} \mathrm{I}^{-1}, 0.33 \mathrm{mmol}$ sodium pyruvate $\mathrm{I}^{-1}, 1.5 \mathrm{mmol}$ glucose $\mathrm{I}^{-1}$ and $0.5 \mathrm{mg}$ polyvinyl alcohol $\mathrm{ml}^{-1}$ (PVA; Sigma, St Louis, MO). The basal medium for IVM (IVMM) was a modified synthetic oviduct fluid (mSOF) described by lkeda et al. (2000). This medium consisted of synthetic oviduct fluid (Tervit et al., 1972), 2\% $(\mathrm{v} / \mathrm{v})$ basal medium Eagle (BME) amino acids solution (Sigma), 1\% ( $\mathrm{v} / \mathrm{v})$ minimum essential medium (MEM) non-essential amino acids solution (Sigma), $0.5 \mathrm{mg}$ PVA $\mathrm{ml}^{-1}, 1.0 \mu \mathrm{g}$ oestradiol $\mathrm{ml}^{-1}$ (Sigma) and $100 \mathrm{iu}$ hCG ml-1 (Sankyo Co., Tokyo).

The medium for IVF was modified Tyrode's balanced salt solution (BO) (Brackett and Oliphant, 1975). The washing medium for frozen-thawed bull spermatozoa was BO supplemented with $10 \mathrm{mmol}$ caffeine sodium benzoate $\mathrm{I}^{-1}$ (Sigma) and $20 \mu \mathrm{g}$ heparin $\mathrm{ml}^{-1}$ (Sigma) (BO-1). The medium used for co-incubation of spermatozoa and oocytes was a 50:50 (v:v) mixture of BO-1 and BO supplemented with $20 \mathrm{mg} \mathrm{BSA} \mathrm{ml}^{-1}$ (Sigma) (BO-2). The medium for in vitro culture (IVC) of embryos after IVF (IVCM) was mSOF described above supplemented with 1 or $5 \%(\mathrm{v} / \mathrm{v})$ heat-inactivated fetal bovine serum (FBS; JRH Biosciences, Lenexa, KS) and without PVA and hormones.

\section{IVM, IVF and IVC of CEOs}

Ovaries collected from Japanese black cattle at a local abattoir were transported to the laboratory within $3 \mathrm{~h}$ in saline $(0.9 \%(\mathrm{w} / \mathrm{v}) \mathrm{NaCl})$ at $35-38^{\circ} \mathrm{C}$. The ovaries were pooled regardless of the stage of the oestrous cycle of the donors. Follicular contents were aspirated from follicles with a diameter of $2-5 \mathrm{~mm}$ and diluted with mPBS. The CEOs consisting of oocytes with homogeneous and evenly granulated cytoplasm and an intact cumulus cell mass were selected from the follicular contents. Groups of 10 CEOs were randomly transferred to $50 \mu \mathrm{l}$ drops of IVMM with or without $10 \%(\mathrm{v} / \mathrm{v})$ FBS, covered with paraffin oil and then cultured for up to $24 \mathrm{~h}$ at $39^{\circ} \mathrm{C}$ in $5 \% \mathrm{CO}_{2}$ in air.

After $24 \mathrm{~h}$ of IVM, some oocytes were freed from cumulus cells and the extrusion of the first polar body was assessed under a microscope to evaluate the nuclear maturation rates. The remaining CEOs were subjected to IVF and IVC as described elsewhere (Ikeda et al., 2000). In brief, after frozen bull semen was thawed, spermatozoa were washed with $\mathrm{BO}-1$, resuspended at a concentration of $4-5 \times 10^{6} \mathrm{ml}^{-1}$ in BO-2 and prepared as a $100 \mu \mathrm{l}$ suspension. Groups of 8-12 CEOs at $24 \mathrm{~h}$ of IVM were transferred into the sperm suspension and incubated for $6 \mathrm{~h}$. Thereafter, oocytes were freed from surrounding cumulus cells and transferred into $50 \mu \mathrm{l}$ drops of IVCM containing $1 \%$ FBS and cultured at $39^{\circ} \mathrm{C}$ under $5 \% \mathrm{CO}_{2}, 5 \% \mathrm{O}_{2}$ and $90 \% \mathrm{~N}_{2}$. At $48 \mathrm{~h}$ after insemination, cleaved embryos of normal morphology were transferred to IVCM containing 5\% FBS and cultured until day 8 (fertilization $=$ day 0$)$. The cleavage rates were assessed at $48 \mathrm{~h}$ after insemination. The percentage of embryos reaching the blastocyst stage was recorded on day 8 .

\section{Morphological analysis of apoptosis}

The CEOs at 0 and $24 \mathrm{~h}$ of IVM were mounted on glass slides, fixed with ethanol:acetic acid (3:1, v:v), stained with $1 \%(\mathrm{w} / \mathrm{v})$ orcein and then observed under a microscope to identify apoptotic cells. Apoptotic cells and bodies were defined on the basis of morphological criteria reported by Yang and Rajamahendran (2000), that is, cells with nuclei containing condensed chromatin that had either aggregated in large compact granular masses that abut the nuclear membrane (marginated chromatin), had shrunken into a single regularly shaped, dense, homogeneously stained mass (pyknotic appearance), or had fragmented into multiple densely stained masses (multiple fragments), or discrete membranebound structures with roughly spherical or ovoid shape containing variable amounts of condensed chromatin, cytoplasm, or of both dispersed in the intercellular spaces (apoptotic bodies).

\section{Extraction of genomic DNA from CEOs}

The individual groups of ten CEOs were washed with $\mathrm{mPBS}$ and transferred into microcentrifuge tubes with $50 \mu \mathrm{lmPBS}$. The tubes, each containing 10 CEOs, were immersed in liquid nitrogen and stored at $-80^{\circ} \mathrm{C}$ until DNA extraction. After thawing, the CEOs were lysed by the addition of $50 \mu \mathrm{l}$ of $\times 2$ strengthened lysis buffer $\left(20 \mathrm{mmol}\right.$ Tris- $\mathrm{HCl} \mathrm{I}^{-1}, 200 \mathrm{mmol} \mathrm{NaCl} \mathrm{I}^{-1}$, $50 \mathrm{mmol}$ EDTA $\mathrm{I}^{-1}, 1 \%(\mathrm{w} / \mathrm{v})$ SDS, $0.2 \mathrm{mg}$ proteinase $\mathrm{K} \mathrm{ml}^{-1}$, $\mathrm{pH}$ 8.0) and incubation at $50^{\circ} \mathrm{C}$ for $18 \mathrm{~h}$ with gentle shaking. The DNA was extracted by the phenol:chloroform:isoamyl alcohol (25:24:1, v:v:v, PCI) method and precipitated using ethanol. The DNA pellets were dried and resuspended in $20 \mu \mathrm{l} \mathrm{TE}$ buffer $(10 \mathrm{mmol}$ Tris- $\mathrm{HCl} \mathrm{I}{ }^{-1}, 1$ mmol EDTA I ${ }^{-1}, \mathrm{pH}$ 8.0). This solution $(20 \mu \mathrm{l})$ contained DNA corresponding to eight CEOs.

PCR reactions upon the $\beta$-actin gene as an internal control were performed using the DNA solution to verify the equality of the amounts of the DNA extracted. Two microlitres of DNA solution (corresponding to 0.8 CEO) was mixed in a $50 \mu \mathrm{l}$ reaction mixture containing $200 \mu \mathrm{mol}$ dNTP $\mathrm{I}^{-1}$, $2.5 \mathrm{U}$ Ex-Taq DNA polymerase (Takara Bio. Inc.) and a pair of primers $\left(0.25 \mu \mathrm{mol} \mathrm{I}^{-1}\right)$ specific for the $\beta$-actin gene and amplified for 30 cycles of $30 \mathrm{~s}$ at $94^{\circ} \mathrm{C}, 30 \mathrm{~s}$ at $60^{\circ} \mathrm{C}$ and $1 \mathrm{~min}$ at $72^{\circ} \mathrm{C}$.

\section{Detection of apoptotic DNA fragmentation by $L M-P C R$}

The detection of the nucleosomal DNA ladder of apoptotic cells was performed using an ApoAlert ligationmediated PCR (LM-PCR) ladder assay kit (Clontech, Palo 
Alto, CA) according to the manufacturer's instructions with minor modifications. Among its advantages, the LMPCR assay is reported to be semiquantitative, allowing comparison of the relative extent of apoptosis in different samples (Staley et al., 1997). Genomic DNA corresponding to three CEOs was mixed with $1 \mathrm{nmol}$ each of $24 \mathrm{bp}$ (5'-AGCACTCTCGAGCCTCTCACCGCA-3') and $12 \mathrm{bp}$ (5'-TGCGGTGAGAGG-3') unphosphorylated oligonucleotides in a $49 \mu \mathrm{l}$ reaction volume with $1 \times$ ligation mix (Clontech). The oligonucleotides were annealed by heating to $55^{\circ} \mathrm{C}$ for $10 \mathrm{~min}$ and cooling gradually to $10^{\circ} \mathrm{C}$ over $1 \mathrm{~h}$ followed by incubation at $10^{\circ} \mathrm{C}$ for $10 \mathrm{~min}$. Four hundred $U(1 \mu \mathrm{l})$ of T4 DNA ligase (Clontech) was added and ligation was performed at $16^{\circ} \mathrm{C}$ for $16 \mathrm{~h}$. This procedure allowed the unphosphorylated adaptors to ligate to the $5^{\prime}$-phosphorylated blunt ends of the DNA fragments generated during the IVM culture. Adaptor-ligated DNA solution $(50 \mu \mathrm{l})$ was stored at $-20^{\circ} \mathrm{C}$ until PCR was performed.

Adaptor-ligated DNA solution $(8 \mu \mathrm{l})$ corresponding to half of a CEO was mixed with $5 \mu$ l of $10 \times$ LM-PCR mix (Clontech) containing the 24 bp oligonucleotides (linker primer) and $36.5 \mu \mathrm{l}$ of water in a PCR tube. The tube was heated to $72^{\circ} \mathrm{C}$ for $3 \mathrm{~min}$ followed by the addition of $2.5 \mathrm{U}(0.5 \mu \mathrm{l})$ of Ex-Taq DNA polymerase and further incubation at $72^{\circ} \mathrm{C}$ for 5 min to fill in the $5^{\prime}$ protruding ends of the ligated DNA. The $24 \mathrm{bp}$ oligonucleotide could now serve as a primer, and the DNA fragments with adaptors on both ends could be exponentially amplified. PCR reactions were performed for 24-26 cycles of $1 \mathrm{~min}$ at $94^{\circ} \mathrm{C}$ and $3 \mathrm{~min}$ at $72^{\circ} \mathrm{C}$.

All of the procedures described above were also performed using the oocytes that were mechanically stripped of cumulus cells at the end of IVM to confirm whether the apoptotic DNA fragmentation detected in the CEOs was derived from cumulus cells or from oocytes.

\section{Assessment of fragmented DNA ends generated in cumulus cell apoptosis}

The mode of DNA cleavage in cumulus cell apoptosis was assessed by pretreating DNA fragments in CEOs either with Klenow enzyme or T4 DNA polymerase, and then subjecting them to LM-PCR analysis as described above. Genomic DNA from 16 CEOs at $24 \mathrm{~h}$ of IVM culture under the control condition was extracted as described above and dissolved in $20 \mu \mathrm{l}$ distilled water. The genomic DNA was treated with either $2 \mathrm{U}$ Klenow enzyme (Takara Bio. Inc.) in $10 \mathrm{mmol}$ Tris-HCl $\mathrm{I}^{-1}$ ( $\mathrm{pH} 7.5), 7.0 \mathrm{mmol} \mathrm{MgCl}_{2} \mathrm{I}^{-1}, 0.1 \mathrm{mmol}$ dithiothreitol $\mathrm{I}^{-1}$ and $20 \mu \mathrm{mol} \mathrm{dNTP} \mathrm{I}^{-1}$ or $4 \mathrm{U}$ T4 DNA polymerase (Toyobo, Osaka) in $50 \mathrm{mmol}$ Tris- $\mathrm{HCl} \mathrm{I^{-1 }}(\mathrm{pH}$ 8.5), $7.0 \mathrm{mmol} \mathrm{MgCl} \mathrm{I}^{-1}, 15 \mathrm{mmol}\left(\mathrm{NH}_{4}\right)_{2} \mathrm{SO}_{4} \mathrm{I}^{-1}, 10 \mathrm{mmol}$ 2-mercaptoethanol $\mathrm{I}^{-1}, 0.1 \mathrm{mmol}$ EDTA $\mathrm{I}^{-1}$ and $0.3 \mathrm{mmol}$ dNTP $\mathrm{I}^{-1}$ for $30 \mathrm{~min}$ at $37^{\circ} \mathrm{C}$. In parallel control reactions, the enzymes were omitted. Enzymes were removed by the $\mathrm{PCl}$ method and the DNA was precipitated using ethanol, dried and resuspended in $20 \mu \mathrm{l}$ of TE buffer. Two microlitres of the DNA solution was subjected to PCR reactions for the $\beta$-actin gene and $7.5 \mu \mathrm{l}$ were used for LM-PCR.

The expected activities of Klenow enzyme and T4 DNA polymerase used in these experiments were confirmed by performing the parallel reaction with the Klenow enzyme on Pvull-BamHI fragments of pBluescript II SK(-) (pBS) plasmid DNA, which have blunt and $5^{\prime}$-overhang ends, and the reaction with the T4 DNA polymerase on Pstl-Asel fragments having $3^{\prime}$ - and 5'overhangs, respectively. Thereafter, the enzyme-treated pBS fragments were subjected to LM-PCR.

\section{Quantification of apoptotic index}

All the PCR products $(50 \mu \mathrm{l})$ were subjected to electrophoresis through $2 \%(\mathrm{w} / \mathrm{v})$ agarose gels containing $0.8 \mu \mathrm{g}$ ethidium bromide $\mathrm{ml}^{-1}$. After electrophoresis for $60 \mathrm{~min}$ at $8 \mathrm{~V} \mathrm{~cm}^{-1}$ in Tris-borate-EDTA buffer, the gels were photographed on a UV transilluminator.

The band intensities of the PCR products were measured by densitometry using a model 4.0 Atto densitograph (Atto, Tokyo). The intensity of ladder-like bands derived from the apoptotic DNA fragments $(<1 \mathrm{~kb})$ was expressed relative to the intensity of the band for $\beta$-actin. The relative intensity for the onset of IVM ( $0 \mathrm{~h})$ was subtracted from that for each time point and the difference was designated as the apoptotic index. Experiments were repeated a minimum of three times.

\section{Statistical analysis}

The statistical analyses of data were performed using the StatView4.02 (Abacus Concepts Inc., Berkeley, CA). Developmental rates were analysed by $t$ test. Raw apoptotic indexes were logarithmically transformed to stabilize the variances, and subjected to one-factor ANOVA and Fisher's PLSD test to detect significant differences among the treatments and time points. Significance was accepted at $P<0.05$.

\section{Results}

The rates of nuclear maturation and development after fertilization of bovine oocytes matured in IVMM with (serum group) or without (control group) serum is shown (Table 1). Most oocytes (> 70\%) achieved nuclear maturation at $24 \mathrm{~h}$ after IVM and cleaved by day 2 after IVF in both groups. The rate of oocytes tested that developed to the blastocyst stage was significantly greater $(P<0.05)$ in the serum-treated group than in the control group. The blastocyst yield from cleaved oocytes was also significantly higher $(P<0.05)$ in the serum-treated group than in the control group. 
Table 1. Effect of serum during in vitro maturation (IVM) on nuclear maturation and development of bovine oocytes after fertilization

\begin{tabular}{|c|c|c|c|c|c|c|}
\hline \multirow[b]{2}{*}{ IVM condition } & \multirow{2}{*}{$\begin{array}{l}\text { Number of } \\
\text { IVM oocytes } \\
\text { (replicates) }\end{array}$} & \multirow{2}{*}{$\begin{array}{l}\text { Nuclear } \\
\text { maturation } \\
(\% \pm \text { SEM })\end{array}$} & \multirow{2}{*}{$\begin{array}{l}\text { Number of } \\
\text { IVM/IVF } \\
\text { oocytes } \\
\text { (replicates) }\end{array}$} & \multirow[b]{2}{*}{$\begin{array}{l}\text { Cleavage } \\
(\% \pm \text { SEM })\end{array}$} & \multicolumn{2}{|c|}{ Blastocyst (\% \pm SEM) } \\
\hline & & & & & $\begin{array}{c}\text { Per IVM/IVF } \\
\text { oocyte }\end{array}$ & $\begin{array}{c}\text { Per cleaved } \\
\text { oocyte }\end{array}$ \\
\hline Control & $56(5)$ & $76.6 \pm 3^{a}$ & 127 (5) & $70.1 \pm 5^{a}$ & $18.3 \pm 2^{\mathrm{a}}$ & $27.3 \pm 4^{\mathrm{a}}$ \\
\hline FBS & $62(5)$ & $76.8 \pm 5^{a}$ & $126(5)$ & $74.8 \pm 5^{\mathrm{a}}$ & $37.7 \pm 4^{b}$ & $52.0 \pm 8^{b}$ \\
\hline
\end{tabular}

a,b Values within the same column with different superscripts are significantly different $(P<0.05)$. FBS: fetal bovine serum.
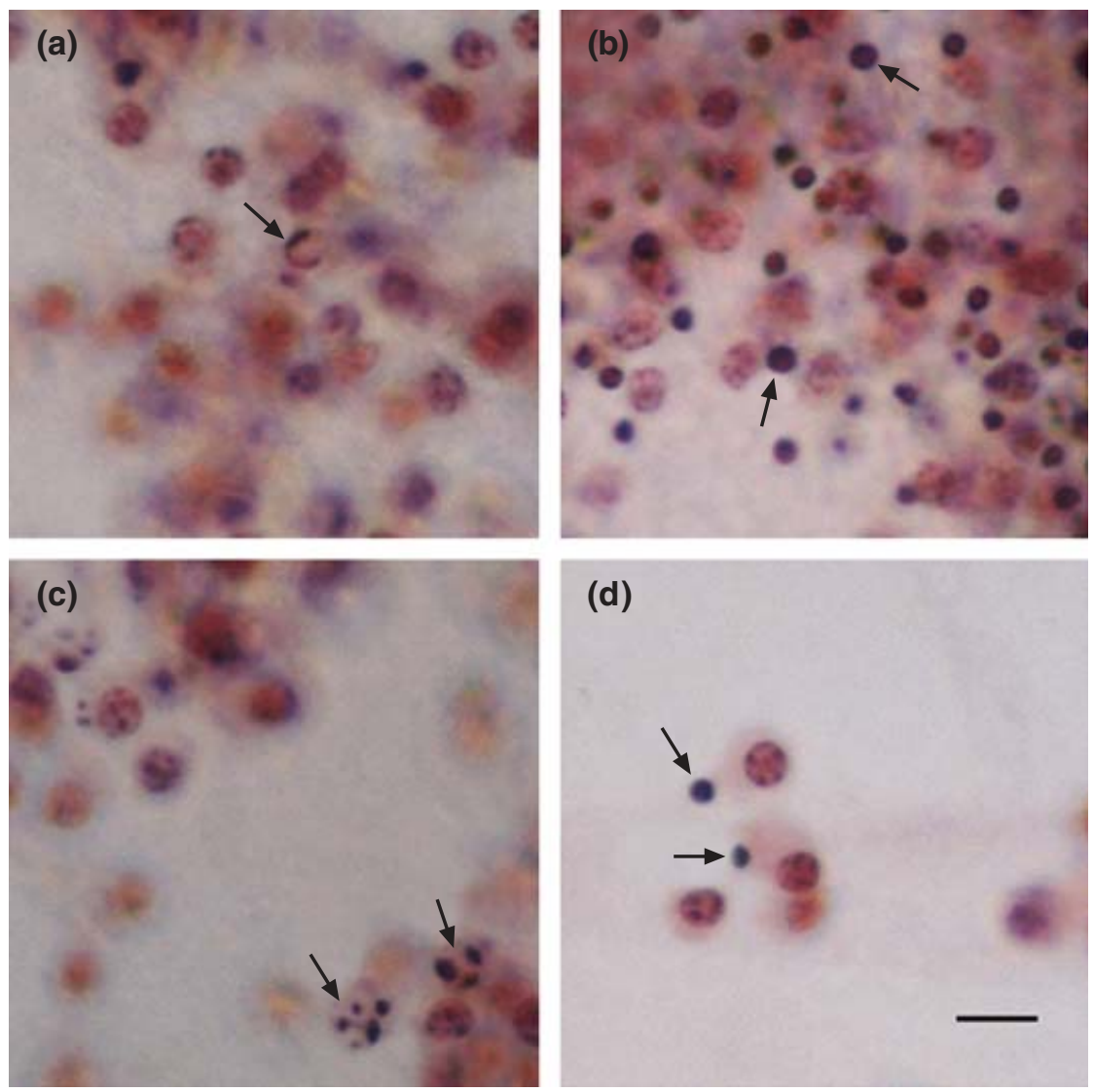

Fig. 1. Morphological features of apoptosis in cumulus cells of bovine cumulusenclosed oocytes (CEOs) at the end of in vitro maturation (IVM) culture. (a) Cells with nuclei containing marginated chromatin, (b) cells with a single small nucleus with densely stained chromatin (pyknotic appearance), (c) cells containing multiple nuclear fragments and (d) membrane-bound structures containing variable amounts of chromatin, cytoplasm, or both (apoptotic bodies). Arrows indicate cumulus cells at each stage of apoptosis. Scale bar represents $10 \mu \mathrm{m}$.

The apoptotic morphological features were hardly seen at the start $(0 \mathrm{~h})$ of IVM, whereas they were evident in cumulus masses of CEOs at the end (24 h) of IVM both in IVMM with and without serum supplementation (Fig. 1). The apoptotic morphological features observed in the cumulus cells were as follows: marginated chromatin (Fig. 1a), pyknotic appearance (Fig. 1b), multiple nuclear fragments (Fig. 1c) and apoptotic bodies (Fig. 1d). The number and distribution of these apoptotic cells and subcellular structures were variable among the CEOs. 
The results of LM-PCR using genomic DNA from bovine CEOs and oocytes matured in serum-free IVMM (CEOs: 0 and $24 \mathrm{~h}$, oocytes: $24 \mathrm{~h}$ of IVM) is shown (Fig. 2). The ladder-like PCR products in CEOs were hardly detectable at $0 \mathrm{~h}$ of IVM, whereas they were clearly visible after $24 \mathrm{~h}$ of culture. The sizes of the ladders were, as expected, 185 bp multiples with an additional $24 \mathrm{bp}$ oligonucleotides at each DNA end. However, no ladder could be obtained from oocytes that were freed from CEOs after $24 \mathrm{~h}$ of culture. Therefore, this finding indicates that the ladder observed in CEOs (24 h) was derived from the DNA of apoptotic cumulus cells.

The time-dependent occurrence of DNA fragmentation characteristic of apoptosis in CEOs during IVM culture with or without serum is shown (Fig. 3). The extent of DNA cleavage into $185 \mathrm{bp}$ multiple ladders significantly increased after $12 \mathrm{~h}$ of culture, and then toward the end of IVM (24 h) irrespective of the addition of serum. When compared at a given time point, the apoptotic index was significantly $(P<0.05)$ lower in the serum-treated group than in the control group at $18 \mathrm{~h}$ of IVM.

The results of LM-PCR on the DNA extracted from CEOs at $24 \mathrm{~h}$ of IVM culture that had been pretreated with either Klenow enzyme or T4 DNA polymerase are shown (Fig. 4a). Filling in 5'-overhangs with Klenow enzyme slightly increased the amplification of ladders (Fig. 4a, lanes 1 and 2), whereas the combination of filling in 5'-overhangs and removing 3'-overhangs with T4 DNA polymerase greatly increased the amplification (Fig. 4a, lanes 3 and 4). Under parallel conditions, Klenow enzyme was shown to fill in the $5^{\prime}$-overhangs of Pvull-BamHI fragments of pBS, and T4 DNA polymerase to fill in and remove the $5^{\prime}$ - and $3^{\prime}$-overhangs of Pstl-Asel fragments, respectively.

\section{Discussion}

Cumulus cells are a subpopulation of granulosa cells that surround the oocyte, providing nutrients and signals that regulate its growth and maturation (Eppig, 1991; Picton et al., 1998; Tanghe et al., 2002). In the present study, it was demonstrated for the first time that cumulus cells of bovine CEOs spontaneously undergo apoptosis during IVM culture. In CEOs collected from the antral follicles of ovaries, the morphological features and a biochemical hallmark of apoptosis (internucleosomal DNA fragmentation) were hardly detectable in the cumulus cells. This finding is consistent with the observation that apoptosis is not found in cumulus cells even in atretic follicles (Yang and Rajamahendran, 2000). In contrast, in the present study, the apoptotic cells and DNA fragmentation markedly increased as the IVM culture proceeded. Luciano et al. (2000) reported that cumulus cells of bovine CEOs cultured in defined media

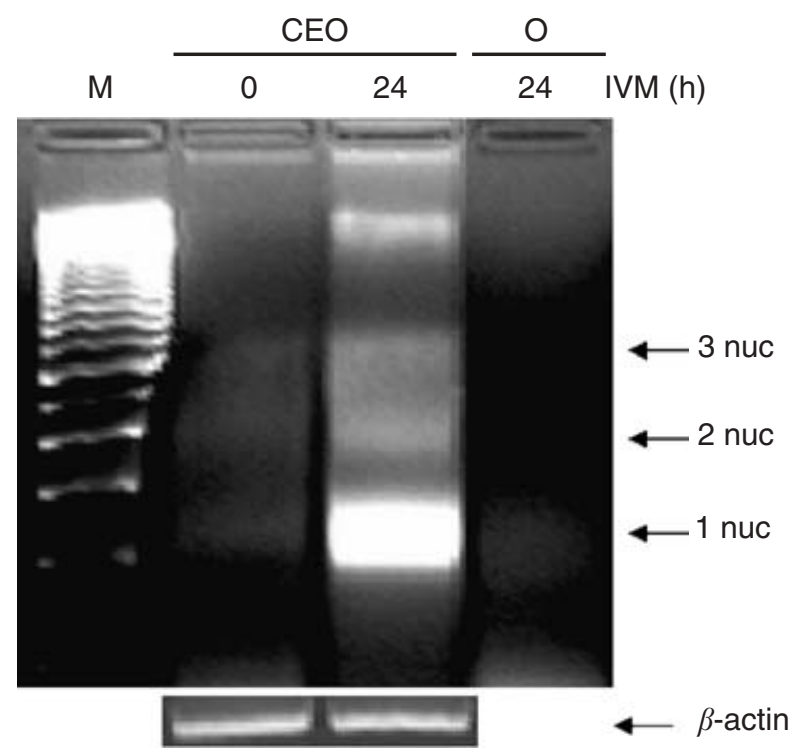

Fig. 2. Ligation-mediated PCR (LM-PCR) analysis of internucleosomal ladder in bovine cumulus-enclosed oocytes (CEOs) cultured for 0 or $24 \mathrm{~h}$ and oocytes (O) matured in vitro (IVM) for $24 \mathrm{~h}$. PCR products derived from adaptor-ligated DNA corresponding to half of a CEO or half of an oocyte were subjected to electrophoresis and then photographed. The lower panel shows a control PCR assay for the $\beta$-actin gene to confirm that equivalent amounts of DNA were analysed. 1 nuc to 3 nuc: the PCR ladder derived from 1 to 3 nucleosomal units of DNA fragments. M: $100 \mathrm{bp}$ DNA marker.

did not undergo apoptosis after $24 \mathrm{~h}$ of IVM, which is not consistent with the findings of the present study. This discrepancy remains to be explained, but it might be attributable to the fact that Luciano et al. (2000) had focused on only a limited number of cumulus cells $(3.2 \times$ $10^{3}$ cells surrounding one oocyte) as the cumulus region, whereas in the present study CEOs with more cumulus cells were used $\left(6-10 \times 10^{3}\right.$ cells per $\left.\mathrm{CEO}\right)$.

The time-course experiments on the detection of DNA fragmentation in the cumulus cells of bovine CEOs during the IVM period showed an induction period both in the control and the serum-treated groups, (for 12 and $18 \mathrm{~h}$ from the beginning of IVM culture, respectively). Thereafter, the degree of DNA fragmentation was accelerated toward the end of IVM in both groups. This finding implies that a self-amplifying drive was involved in apoptosis. The difference in the duration of the induction period between the control and the serum-treated groups may reflect the effects of the different culture conditions upon the apoptotic drive. In addition, apoptosis in cumulus cells during IVM of CEOs occurred irrespective of addition of serum, although serum deprivation is a well-known apoptosisinducing stimulus for granulosa cells (Tilly et al., 1992; Guthrie et al., 1998; Peng et al., 1998; Hu et al., 2001), indicating that serum addition is not sufficient to prevent the cumulus cells from undergoing apoptosis during IVM. 
(a)

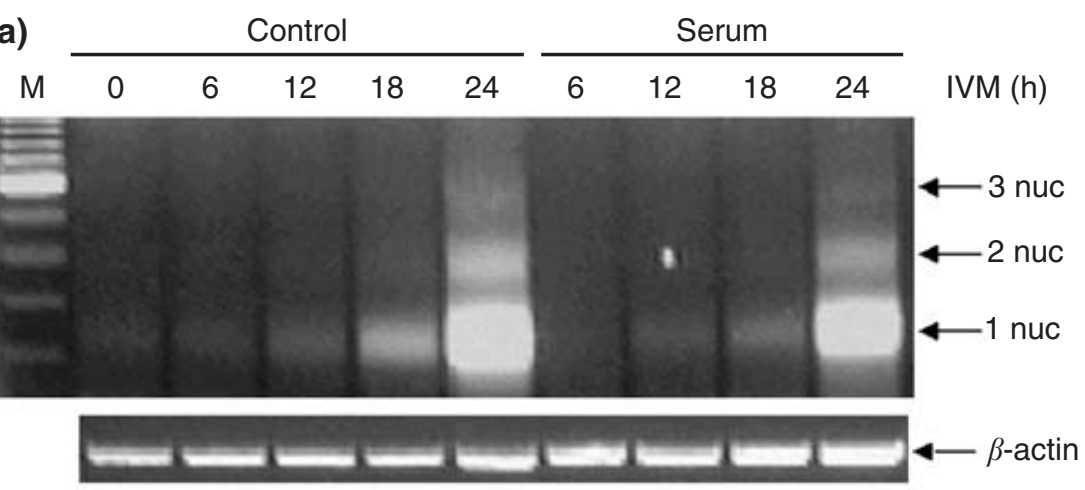

(b)

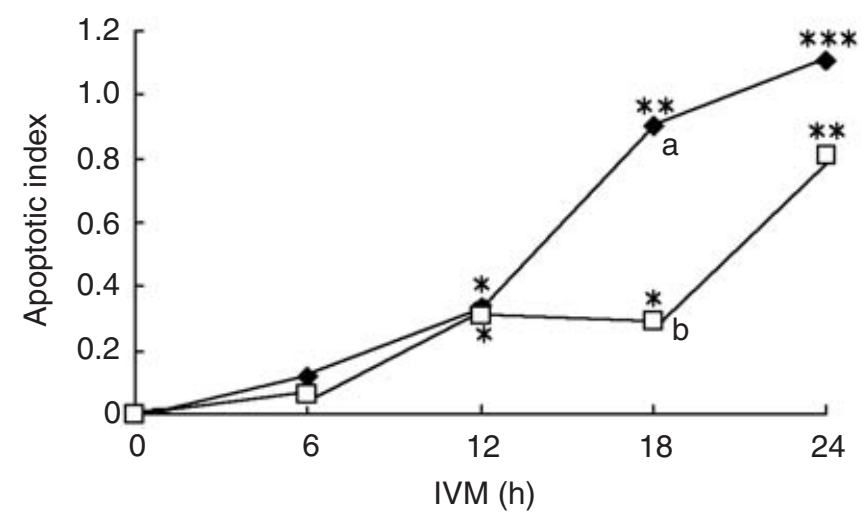

Fig. 3. (a) Ligation-mediated PCR (LM-PCR) analysis of internucleosomal ladder in bovine cumulus-enclosed oocytes (CEOs) during in vitro maturation (IVM) culture with or without addition of serum. M: 100 bp DNA marker. (b) Apoptotic index calculated from the results of the LM-PCR assay during IVM culture. Values with asterisks differ significantly from the value at $0 \mathrm{~h}\left({ }^{*} P<0.05,{ }^{* *} P<0.01,{ }^{* * *} P<0.001\right)$. Different letters depict significant differences between the treatments at the same time point $(P<0.05)$. $\diamond$, Control; $\square$, serum.

It is not known whether apoptosis occurs in cumulus cells during natural oocyte maturation in cyclic follicle recruitment in cattle. However, Szoltys et al. (2000) reported that apoptotic cumulus cells were not detected $1-2 \mathrm{~h}$ before ovulation, and were generally scarce and confined to the peripheral parts of CEOs even at 9-10 h after ovulation in rats showing a regular oestrous cycle. Thus, it seems likely that apoptosis does not occur in cumulus cells of CEOs that are in the ovarian follicle, at least during natural oocyte maturation. If the degree of cumulus cell apoptosis during oocyte maturation differs between ovarian follicles in animals showing a natural oestrous cycle and IVM, the apoptosis observed in IVM is not a physiological, but an artificial phenomenon. This aspect is interesting from the viewpoint of investigating the differences between the in vivo and in vitro maturation of oocytes.

Many studies have determined the incidence of apoptosis in cumulus cells in human CEOs obtained by hyperstimulation for IVF or intracytoplasmic sperm injection (ICSI) programmes (Nakahara et al., 1997a,b; Host et al., 2000, 2002; Lee et al., 2001; Raman et al., 2001). Hyperstimulation is also an artificial technique that overrides natural follicle recruitment and oocyte maturation. The apoptosis reported in these studies might also be due to the non-physiological oocyte maturation.

Furthermore, these studies were all concerned with the relationship between apoptosis in cumulus cells and the developmental competence of the corresponding oocytes. Except for the report by Raman et al. (2001), these previous studies indicate that a low degree of apoptosis in cumulus cells of CEOs is correlated with a higher developmental competence after IVF or ICSI. In the present study, apoptosis was observed irrespective of addition of serum in cumulus cells of bovine CEOs during the IVM period; however, the degree of apoptosis was lower in CEOs cultured with serum. The developmental competence of CEOs assessed by blastocyst development after IVF was significantly higher in the serum-treated 
group than in the control group. Therefore, the viability of cumulus cells of bovine CEOs in IVM culture might be correlated with the greater competence of the oocytes.

Although LM-PCR is a method to detect only DNA fragments with blunt ends (Staley et al., 1997), substantial amounts of such fragments were detected in the present study. In the present study, the characteristic forms of DNA ends generated by DNA fragmentation in the cumulus cell apoptosis during IVM were assessed. When the $5^{\prime}$-overhangs were filled in by Klenow enzyme treatment, the amplification of ladders was slightly increased. However, when both the 5'- and 3'-overhangs were changed to blunt ends by T4 DNA polymerase, the amplification was greatly increased. These results indicate that the characteristic forms of the DNA ends are mainly 3 '-overhangs and blunt ends. This finding provides insight into the nucleases involved in apoptosis in cumulus cells. Deoxyribonuclease I (DNase I) cleaves nucleosomal DNA to produce DNA fragments with short 3'-overhangs (Lutter, 1979; Cusick et al., 1989). Boon and Tsang (1997) reported that DNase I was immunolocalized in nuclei of antral follicle granulosa cells in rats. Caspase-activated nuclease (CPAN), also known as the $40 \mathrm{kDa}$ subunit of DNA fragmentation factor (DFF40), is a deoxyribonuclease which generates blunt ends and 5'-overhangs (Liu et al., 1999; Widlak et al., 2000). Furthermore, because double-stranded DNA breaks are apoptotic signals, the cleavage of genomic DNA by CPAN is considered to trigger an amplifying cycle of apoptosis (Liu et al., 1999). The possible involvement of such a self-amplifying drive is consistent with the results of the time course experiments reported here. Therefore, these endonucleases might be responsible for apoptotic DNA fragmentation in cumulus cells during IVM.

The apoptosis-inhibiting effect of serum on granulosa cells has been considered to be due to the growth factors, such as insulin-like growth factor I, epidermal growth factor and basic fibroblast growth factor that it contains (Quirk et al., 2000). The reduced amount of apoptosis in cumulus cells treated with serum during IVM in the present study may also be attributed to the action of such factors. However, it was noted that the apoptosis of cumulus cells occurs irrespective of the presence of serum and the possibility that cumulus cell apoptosis observed in IVM is substantially different from granulosa cell apoptosis with respect to the growth factor dependency cannot be ruled out.

In summary, the results of the present study demonstrate that cumulus cells of bovine CEOs undergo apoptosis during IVM culture. The difference in cumulus cell apoptosis between natural oocyte maturation and IVM, the relationship between cumulus cell apoptosis and the developmental competence of the corresponding oocytes, and the mechanisms of cumulus cell apoptosis seem worthy of further investigation. (a)
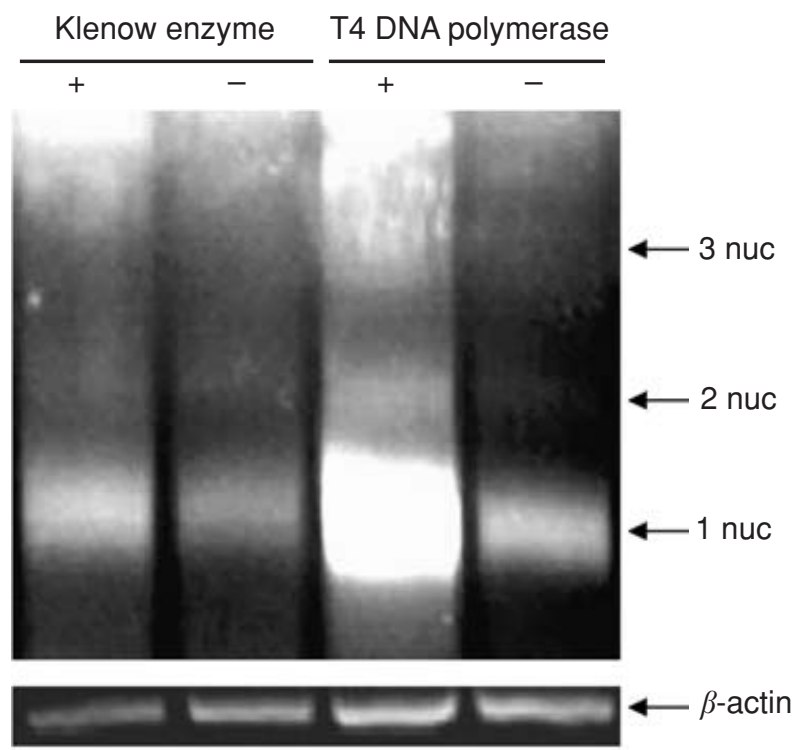

(b)

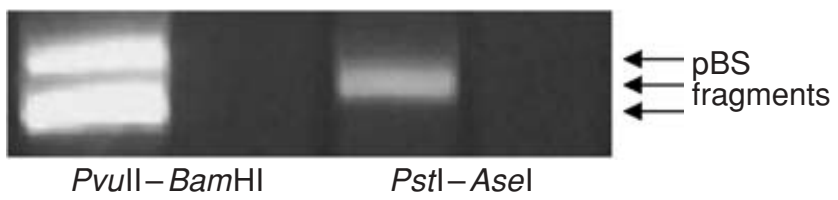

Fig. 4. (a) Ligation-mediated PCR (LM-PCR) analysis in combination with Klenow enzyme or T4 DNA polymerase reaction. Genomic DNA extracted from bovine cumulus-enclosed oocytes (CEOs) at $24 \mathrm{~h}$ of in vitro maturation (IVM) culture under the serumfree condition was treated with (+) or without (-) Klenow enzyme or T4 DNA polymerase and subjected to LM-PCR. (b) The enzymes used in this experiment showed the expected activities in parallel reactions on fragments of pBluescript II SK(-) (pBS). Klenow enzyme was shown to fill in the $5^{\prime}$-overhangs of Pvull-BamHI fragments, whereas T4 DNA polymerase filled in and removed the $5^{\prime}-$ and 3'-overhangs of Pstl-Asel fragments.

This work was supported in part by Grants-in-Aid for Scientific Research from the Ministry of Education, Culture, Sports, Science and Technology, Japan. The authors thank the staff at the Second Wholesale Market of Kyoto City, especially K. Naka and T. Ohnishi, for allowing us access to bovine ovaries.

\section{References}

Boone DL and Tsang BK (1997) Identification and localization of deoxyribonuclease I in the rat ovary Biology of Reproduction 57 813821

Brackett BG and Oliphant G (1975) Capacitation of rabbit spermatozoa in vitro. Biology of Reproduction 12 260-274

Cusick ME, Wassarman PM and DePamphilis ML (1989) Application of nucleases to visualizing chromatin organization at replication forks Methods in Enzymology 170 290-316

Eppig JJ (1991) Intercommunication between mammalian oocytes and companion somatic cells Bioessays 13 569-574

Ginther OJ, Beg MA, Bergfelt DR, Donadeu FX and Kot K (2001) Follicle selection in monovular species Biology of Reproduction $\mathbf{6 5}$ 638-647 
Guthrie HD, Garrett WM and Cooper BS (1998) Follicle-stimulating hormone and insulin-like growth factor I attenuate apoptosis in cultured porcine granulosa cells Biology of Reproduction 58 390-396

Host E, Mikkelsen AL, Lindenberg S and Smidt-Jensen S (2000) Apoptosis in human cumulus cells in relation to maturation stage and cleavage of the corresponding oocyte Acta Obstetricia et Gynecologica Scandinavica 79 936-940

Host E, Gabrielsen A, Lindenberg S and Smidt-Jensen S (2002) Apoptosis in human cumulus cells in relation to zona pellucida thickness variation, maturation stage, and cleavage of the corresponding oocyte after intracytoplasmic sperm injection Fertility and Sterility 77 511-515

Hu CL, Cowan RG, Harman RM, Porter DA and Quirk SM (2001) Apoptosis of bovine granulosa cells after serum withdrawal is mediated by Fas antigen (CD95) and Fas ligand Biology of Reproduction 64 518-526

Ikeda S, Ichihara-Tanaka K, Azuma T, Muramatsu T and Yamada M (2000) Effects of midkine during in vitro maturation of bovine oocytes on subsequent developmental competence Biology of Reproduction 63 1067-1074

Jolly PD, Tisdall DJ, Heath DA, Lun S and McNatty KP (1994) Apoptosis in bovine granulosa cells in relation to steroid synthesis, cyclic adenosine $3^{\prime}, 5^{\prime}$-monophosphate response to follicle-stimulating hormone and luteinizing hormone, and follicular atresia Biology of Reproduction $\mathbf{5 1}$ 934-944

Kim KS, Minami N, Yamada M and Utsumi K (1997) Follicular cells affect the fertilizability and developmental competency of bovine oocytes in vitro. Reproduction, Fertility and Development 9 763-766

Lee KS, Joo BS, Na YJ, Yoon MS, Choi OH and Kim WW (2001) Cumulus cells apoptosis as an indicator to predict the quality of oocytes and the outcome of IVF-ET Journal of Assisted Reproduction and Genetics 18 490-498

Liu X, Zou H, Widlak P, Garrard W and Wang X (1999) Activation of the apoptotic endonuclease DFF40 (caspase-activated DNase or nuclease). Oligomerization and direct interaction with histone $\mathrm{H} 1$ Journal of Biological Chemistry $27413836-13840$

Luciano AM, Modina S, Gandolfi F, Lauria A and Armstrong DT (2000) Effect of cell-to-cell contact on in vitro deoxyribonucleic acid synthesis and apoptosis responses of bovine granulosa cells to insulin-like growth factor-I and epidermal growth factor Biology of Reproduction 631580 1585

Lutter LC (1979) Precise location of DNase I cutting sites in the nucleosome core determined by high resolution gel electrophoresis Nucleic Acids Research 6 41-56

Manabe N, Imai Y, Ohno $\mathbf{H}$, Takahagi $Y$, Sugimoto $\mathbf{M}$ and Miyamoto $\mathbf{H}$ (1996) Apoptosis occurs in granulosa cells but not cumulus cells in the atretic antral follicles in pig ovaries Experientia 52 647-651

Nagai T (2001) The improvement of in vitro maturation systems for bovine and porcine oocytes Theriogenology 55 1291-1301

Nakahara K, Saito H, Saito T, Ito M, Ohta N, Takahashi T and Hiroi M (1997a) The incidence of apoptotic bodies in membrana granulosa can predict prognosis of ova from patients participating in in vitro fertilization programs Fertility and Sterility $68312-317$

Nakahara K, Saito H, Saito T, Ito M, Ohta N, Sakai N, Tezuka N, Hiroi M and Watanabe $\mathbf{H}$ (1997b) Incidence of apoptotic bodies in membrana granulosa of the patients participating in an in vitro fertilization program Fertility and Sterility 67 302-308

Peng X, Maruo T, Matsuo H, Takekida S and Deguchi J (1998) Serum deprivation-induced apoptosis in cultured porcine granulosa cells is characterized by increased expression of p53 protein, Fas antigen and Fas ligand and by decreased expression of PCNA Endocrine Journal 45 247-253

Picton H, Briggs D and Gosden R (1998) The molecular basis of oocyte growth and development Molecular and Cellular Endocrinology 145 27-37

Quirk SM, Harman RM and Cowan RG (2000) Regulation of Fas antigen (Fas, CD95)-mediated apoptosis of bovine granulosa cells by serum and growth factors Biology of Reproduction 63 1278-1284

Raman RS, Chan PJ, Corselli JU, Patton WC, Jacobson JD, Chan SR and King A (2001) Comet assay of cumulus cell DNA status and the relationship to oocyte fertilization via intracytoplasmic sperm injection Human Reproduction 16 831-835

Staley K, Blaschke AJ and Chun J (1997) Apoptotic DNA fragmentation is detected by a semiquantitative ligation-mediated PCR of blunt DNA ends Cell Death and Differentiation 4 66-75

Szoltys M, Tabarowski Z and Pawlik A (2000) Apoptosis of postovulatory cumulus granulosa cells of the rat Anatomy and Embryology 202 523-529

Tanghe S, Van Soom A, Nauwynck H, Coryn $M$ and de Kruif A (2002) Minireview: functions of the cumulus oophorus during oocyte maturation, ovulation and fertilization Molecular Reproduction and Development 61 414-424

Tervit HR, Whittingham DG and Rowson LE (1972) Successful culture in vitro of sheep and cattle ova Journal of Reproduction and Fertility 30 493-497

Tilly JL, Billig H, Kowalski KI and Hsueh AJ (1992) Epidermal growth factor and basic fibroblast growth factor suppress the spontaneous onset of apoptosis in cultured rat ovarian granulosa cells and follicles by a tyrosine kinase-dependent mechanism Molecular Endocrinology 6 1942-1950

Widlak P, Li P, Wang X and Garrard WT (2000) Cleavage preferences of the apoptotic endonuclease DFF40 (caspase-activated DNase or nuclease) on naked DNA and chromatin substrates Journal of Biological Chemistry 275 8226-8232

Yang MY and Rajamahendran R (2000) Morphological and biochemical identification of apoptosis in small, medium, and large bovine follicles and the effects of follicle-stimulating hormone and insulin-like growth factor-I on spontaneous apoptosis in cultured bovine granulosa cells Biology of Reproduction 62 1209-1217

Zhang L, Jiang S, Wozniak PJ, Yang X and Godke RA (1995) Cumulus cell function during bovine oocyte maturation, fertilization and embryo development in vitro. Molecular Reproduction and Development 40 338-344

Resubmitted manuscript received 8 October 2002.

Accepted 19 November 2002. 